\title{
Effect of atmospheric carbon dioxide concentration on the cultivation of bovine Mycoplasma species
}

\author{
J. L. Lowe, ${ }^{*}$ L. K. Fox, ${ }^{*} \dagger^{1}$ B. D. Enger, $\ddagger$ A. Adams Progar, ${ }^{*}$ and J. M. Gay $†$ \\ *Department of Animal Sciences, and \\ †Department of Veterinary Clinical Sciences, Washington State University, Pullman 99164 \\ ‡Department of Dairy Science, Virginia Polytechnic Institute and State University, Blacksburg 24061
}

\begin{abstract}
Recommendations for bovine mycoplasma culture $\mathrm{CO}_{2}$ concentrations are varied and were not empirically derived. The objective of this study was to determine whether the growth measures of bovine mycoplasma isolates differed when incubated in $\mathrm{CO}_{2}$ concentrations of 10 or $5 \%$ or in candle jars $\left(2.7 \pm 0.2 \% \mathrm{CO}_{2}\right)$. Growth of Mycoplasma bovis ( $\mathrm{n}=22)$, Mycoplasma californicum $(\mathrm{n}=18)$, and other Mycoplasma spp. $(\mathrm{n}=10)$ laboratory isolates was evaluated. Isolate suspensions were standardized to approximately $10^{8} \mathrm{cfu} / \mathrm{mL}$ and serially diluted in pasteurized whole milk to achieve test suspensions of $10^{2}$ and $10^{6} \mathrm{cfu} / \mathrm{mL}$. One hundred microliters of each test dilution was spread in duplicate onto the surface of a modified Hayflick's agar plate. Colony growth was enumerated on $\mathrm{d} 3,5$, and 7 of incubation. A mixed linear model included the fixed effects of $\mathrm{CO}_{2}$ treatment $(2.7,5$, or $10 \%)$, species, day $(3,5$, or 7$)$, and their interactions, with total colony counts as the dependent variable. Carbon dioxide concentration did not significantly affect overall mycoplasma growth differences, but differences between species and day were present. Colony counts $\left(\log _{10} \mathrm{cfu} /\right.$ $\mathrm{mL}$ ) of $M$. bovis were 2.6- and 1.6-fold greater than $M$. californicum and other Mycoplasma spp., respectively. Growth at $7 \mathrm{~d}$ of incubation was greater than $\mathrm{d} 3$ and 5 for all species. These findings were confirmed using field isolates $(\mathrm{n}=98)$ from a commercial veterinary diagnostic laboratory. Binary growth responses (yes/ no) of the field isolates were not different between $\mathrm{CO}_{2}$ treatments but did differ between species and day of incubation. On average, $57 \%$ of all field isolates were detected by $3 \mathrm{~d}$ of incubation compared with $93 \%$ on $\mathrm{d}$ 7. These results suggest that the range of suitable $\mathrm{CO}_{2}$ culture conditions and incubation times for the common mastitis-causing Mycoplasma spp. may be broader than currently recommended.
\end{abstract}

Received August 29, 2017.

Accepted January 6, 2018.

${ }^{1}$ Corresponding author: fox@wsu.edu
Key words: mastitis, Mycoplasma spp., culture, carbon dioxide

\section{INTRODUCTION}

Mycoplasma mastitis, first described by Hale et al. (1962), is an important disease of the dairy industry worldwide. Due to decreased milk production and quality, mycoplasma mastitis causes an approximately $\$ 108$ million annual loss in the US industry (Rosenbusch as cited by Rosengarten and Citti, 1999). The predominant Mycoplasma spp. causing mastitis are Mycoplasma bovis and Mycoplasma californicum; Mycoplasma bovigenitalium, Mycoplasma alkalescens, and Mycoplasma canadense are less frequently isolated from mastitic cows and bulk tank milk samples (González and Wilson, 2003). As contagious organisms, these pathogens can affect a cow in any stage of lactation, including the dry period (Jasper, 1982). As with other contagious pathogens such as Staphylococcus aureus and Streptococcus agalactiae, transmission of mycoplasma mastitis is believed to occur during milking (González and Wilson, 2003), but the ability of mycoplasmas to colonize other body sites that do not directly contact other animals suggests that other modes of transmission via blood, lymph, or aerosols may occur (Fox, 2012). Because of these factors, control strategies rely heavily on identification and culling of infected animals (Fox et al., 2005).

The National Mastitis Council (Middleton et al., 2017) currently recommends isolating mycoplasma by spreading $100 \mu \mathrm{L}$ of milk onto a modified Hayflick's agar plate and incubating at $37^{\circ} \mathrm{C}$ under microaerophilic conditions $\left(10 \% \mathrm{CO}_{2}\right)$ for 7 to $10 \mathrm{~d}$. This recommendation is derived from the initial report of $M$. bovis mastitis by Hale et al. (1962) in which incubation for $5 \mathrm{~d}$ in $10 \% \mathrm{CO}_{2}$ yielded isolates. However, other studies have reported successfully cultivating mycoplasma from avian, bovine, and cell culture sources when using either a candle jar to limit oxygen tension or $5 \% \mathrm{CO}_{2}$ (Fabricant et al., 1962; Stipkovits et al., 1975; Amin and Jordan, 1978; Polak-Vogelzang et al., 1983; Kotani et al., 1990; Nicholas and Baker, 1998; Parker et al., 
2017). With such atmosphere variability in mycoplasma culture conditions reported in the literature and with Mycoplasma spp. becoming more prevalent, empirical evaluation of isolation protocols may lead to improved mycoplasma mastitis diagnosis. The objective was to determine whether bovine mycoplasma isolates differ in growth measures when incubated in $\mathrm{CO}_{2}$ concentrations of 10 or $5 \%$ or in candle jars $\left(2.7 \pm 0.2 \% \mathrm{CO}_{2}\right)$. Using these findings, veterinary diagnosticians may be able to select a more optimal atmosphere for culturing mycoplasma pathogens from milk.

\section{MATERIALS AND METHODS}

\section{Laboratory Isolates}

Mycoplasma bovis $(\mathrm{n}=22), M$. californicum $(\mathrm{n}=18)$, M. bovigenitalium $(\mathrm{n}=5)$, and Mycoplasma arginini ( $\mathrm{n}$ $=5$ ) laboratory isolates were selected from the Washington State University Field Disease Investigative Unit culture collection and were filtration-cloned before use for the first study (Boonyayatra et al., 2012). Herein, these M. bovigenitalium and M. arginini isolates are collectively referred to as Mycoplasma spp. $(\mathrm{n}=10)$. Species verification was performed by PCR-RFLP analysis (Tang et al., 2000; Boonyayatra et al., 2012). Bulk tank milk $(3 \mathrm{~L})$ was collected from the Washington State University herd, and $250-\mathrm{mL}$ portions were split into sterilized $500-\mathrm{mL}$ beakers for pasteurization by microwave. Milk was microwaved with a household microwave (model no. EM-1100S, Sanyo Electronics, Little Ferry, $\mathrm{NJ}$ ) at the highest setting for $3.5 \mathrm{~min}$; the microwaving was periodically interrupted to swirl the milk in the beaker. Aliquots $(100 \mu \mathrm{L})$ were removed from the beaker and cultured on Columbia blood agar (Hardy Diagnostic), and plates were incubated aerobically for $48 \mathrm{~h}$ at $37^{\circ} \mathrm{C}$. Only microwaved milk free of bacterial growth as tested was used and was stored frozen $\left(-15^{\circ} \mathrm{C}\right)$ until needed. Isolates to be tested were defrosted at ambient temperature, and $400 \mu \mathrm{L}$ of culture stock was transferred to $40 \mathrm{~mL}$ of sterile pleuropneumonia-like organisms (PPLO) broth. Inoculants were incubated at $37^{\circ} \mathrm{C}$ in $10 \% \mathrm{CO}_{2}$ for $5 \mathrm{~d}$. Broth cultures of the mycoplasma strains were then centrifuged at $5,000 \times g$ for $30 \mathrm{~min}$. The cell pellet was suspended in $20 \mathrm{~mL}$ of PBS solution and centrifuged for a total of 3 resuspensions or washings. Washed cells were suspended in $3 \mathrm{~mL}$ of PBS solution. The mycoplasma suspension was diluted to achieve an optical density of 0.2 at $540 \mathrm{~nm}$ (Punyapornwithaya et al., 2010). Mycoplasma suspensions were subsequently serially diluted with pasteurized bulk tank milk collected to achieve target concentrations that would produce several colonies in a visually countable range. The milk samples were incubated for
$24 \mathrm{~h}$ at $37^{\circ} \mathrm{C}$ in $10 \% \mathrm{CO}_{2}$. To enumerate colony growth, a $100-\mu \mathrm{L}$ portion of inoculated samples was serially diluted and $100-\mu \mathrm{L}$ portions were spread onto the entire surface of a modified Hayflick's agar plate (BD BBL, Thermo Fisher Scientific Inc., Waltham, MA). Petri dishes were incubated at $37^{\circ} \mathrm{C}$ under various $\mathrm{CO}_{2}$ concentrations: incubators set at 10 and $5 \% \mathrm{CO}_{2}$ and in 1-gallon jars with a metal screw cap containing a lit unscented votive candle (Mainstays, Walmart Inc., Bentonville, AR) that produced an average $\mathrm{CO}_{2}$ atmosphere of $2.7 \pm 0.2 \%$. To verify $\mathrm{CO}_{2}$ concentrations, a 0 to $30 \% \mathrm{CO}_{2}$, temperature, and relative humidity data logger (CM-0017, CO2Meter.com, Ormond Beach, FL) was used. Candle jars were opened only on the day of enumeration, and all plates were discarded after counting. Colonies on each plate with the characteristic "fried egg" appearance as examined using a dissecting microscope $(15 \times$ magnification) were first enumerated on $\mathrm{d} 3,5$, and 7 of incubation.

\section{Field Isolates}

Clinical mycoplasma mastitis field samples $(\mathrm{n}=304)$ were used in a second experiment to verify the findings from the laboratory isolates. These were collected over a 19-mo period by a commercial veterinary diagnostic laboratory (Dairy Vet Management, Sunnyside, WA) from sample submissions confirmed to contain mycoplasma-like species. Samples were kept frozen $\left(-15^{\circ} \mathrm{C}\right)$ and were defrosted at ambient temperature immediately before use, and $100 \mu \mathrm{L}$ was spread onto the entire surface of a modified Hayflick's agar plate. Petri dishes were incubated and examined as above after 3 and $7 \mathrm{~d}$ of incubation.

A representative colony was extracted from plates with growth $(\mathrm{n}=98)$ after $7 \mathrm{~d}$ of incubation, inoculated into $10 \mathrm{~mL}$ of sterile PPLO broth, and incubated for $5 \mathrm{~d}$ in $10 \% \mathrm{CO}_{2}$. Genomic DNA was extracted with the PureLink Genomic DNA Mini Kit (Invitrogen, Carlsbad, CA) according to the user manual provided with the kit. Species identification was performed using a nested PCR-RFLP analysis (Tang et al., 2000; Boonyayatra et al., 2012). Polymerase chain reaction was performed in a total volume of $50 \mu \mathrm{L}$ containing $1 \times$ PCR buffer $(20$

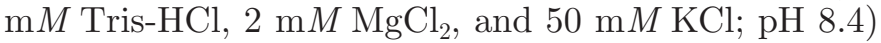
and $50 \mu M$ each of deoxynucleoside triphosphates, 20 pmol of each primer, and $1 \mathrm{U}$ of Taq DNA polymerase (Invitrogen). A set of primers including F2, R2, and R34 (Tang et al., 2000) was used to amplify the 16S and 23S rRNA intergenic spacer regions of Mycoplasma and Acholeplasma. Five microliters of DNA extract was used as a template by adding it into $45 \mu \mathrm{L}$ of reaction mixture. The thermal cycling protocol was performed on an iCycler (Bio-Rad, Hercules, CA) with the follow- 
ing conditions: 1 cycle of $94^{\circ} \mathrm{C}$ for $30 \mathrm{~s} ; 30$ cycles for the first-stage PCR (or 35 cycles for the second-stage PCR) of $94^{\circ} \mathrm{C}$ for $30 \mathrm{~s} ; 1$ cycle of $55^{\circ} \mathrm{C}$ for 2 min; 1 cycle of $72^{\circ} \mathrm{C}$ for $2 \mathrm{~min}$; and 1 cycle of $72^{\circ} \mathrm{C}$ for $5 \mathrm{~min}$. Products were digested with AseI for RFLP analysis. Products were electrophoresed on a $2 \%$ agarose gel, and patterns of DNA fragments were visualized by UV fluorescence (Boonyayatra et al., 2012).

\section{Statistical Analysis}

Laboratory Isolates. The UNIVARIATE procedure of SAS 9.3 (SAS Institute Inc., Cary, NC) was used to confirm that the data were normally distributed. The MIXED procedure of SAS 9.3 was used to evaluate the fixed effects of treatment $\left(2.7,5\right.$, or $\left.10 \% \mathrm{CO}_{2}\right)$, species (M. bovis, M. californicum, or Mycoplasma spp.), and day $(3,5$, or 7$)$ and their interactions on enumerations $\left(\log _{10} \mathrm{cfu} / \mathrm{mL}\right)$. All main effects were retained, and stepwise backward elimination was used to remove nonsignificant interactions $(P \geq 0.05)$. Three individual species models were used to evaluate the fixed effects of treatment $\left(2.7,5\right.$, or $\left.10 \% \mathrm{CO}_{2}\right)$ and day $(3,5$, or 7$)$ and their interactions on enumerations $\left(\log _{10} \mathrm{cfu} / \mathrm{mL}\right)$. In the instance of the M. californicum and Mycoplasma spp. models, a compound symmetry covariance structure was specified and used to account for unequal variances. Means for the respective models were compared using Fisher's least significant differences test.

Field Isolates. The GLIMMIX procedure in SAS 9.3 with a logit link and binomial error distribution was used to model the probability of growth (yes/no) for field isolates. The variables of interest were $\mathrm{CO}_{2}$ concentration $(2.7,5$, or $10 \%)$ and incubation length (3 or $7 \mathrm{~d})$, and differences among species recovered $(M$. bovis, M. californicum, Acholeplasma axanthum, and Mycoplasma spp.) were compared.

\section{RESULTS}

\section{Laboratory Isolates}

All plates yielded growth, with a minimum organism recovery of $3.98 \mathrm{cfu} / \mathrm{mL}$ of sample. Overall, mean isolate $\log _{10}$ colony-forming unit enumerations were not significantly influenced by the 3 tested $\mathrm{CO}_{2}$ concentrations $(P=0.65)$; the average enumeration $( \pm$ SEM $)$ of all mycoplasma isolates incubated within a candle jar, $5 \% \mathrm{CO}_{2}$, and $10 \% \mathrm{CO}_{2}$ were $4.72 \pm 0.22,4.74 \pm$ 0.22 , and $4.68 \pm 0.22 \log _{10} \mathrm{cfu} / \mathrm{mL}$, respectively. Day of incubation was significantly different across all species, with enumerations increasing from $4.43 \pm 0.22 \log _{10}$ $\mathrm{cfu} / \mathrm{mL}$ after $3 \mathrm{~d}$ of incubation to $4.91 \pm 0.22 \log _{10} \mathrm{cfu} /$ $\mathrm{mL}(P=0.0013)$ at $7 \mathrm{~d}$ of incubation. Additionally, differences in enumerated growth among species were identified $(P<0.0001)$. Across all $\mathrm{CO}_{2}$ concentrations, $M$. bovis isolates had the greatest enumerated growth at $7 \mathrm{~d}$ of incubation $\left(8.14 \pm 0.04 \log _{10} \mathrm{cfu} / \mathrm{mL}\right)$, followed by Mycoplasma spp. $\left(4.56 \pm 0.07 \log _{10} \mathrm{cfu} / \mathrm{mL}\right)$ and M. californicum $\left(4.46 \pm 0.12 \log _{10} \mathrm{cfu} / \mathrm{mL}\right)$. Within bacterial species, significant differences were detected between strains of bacteria $(P<0.05)$.

The average $M$. bovis isolate enumeration ( \pm SEM) was $8.02 \pm 0.04,8.09 \pm 0.04$, and $8.08 \pm 0.04 \log _{10} \mathrm{cfu} /$ $\mathrm{mL}$ when incubated for $7 \mathrm{~d}$ within a candle jar, $5 \%$ $\mathrm{CO}_{2}$, or $10 \% \mathrm{CO}_{2}$, respectively, and differences were not significant $(P=0.14$; Figure 1$)$. All isolates were detected by $3 \mathrm{~d}$ of incubation regardless of $\mathrm{CO}_{2}$ concentration, though $\log _{10}$ enumerations were significantly greater after $7 \mathrm{~d}$ of incubation $(P=0.01$; Figure 2$)$. Across all $\mathrm{CO}_{2}$ concentrations, enumerations ( \pm SEM) increased from $8.04 \pm 0.04 \log _{10} \mathrm{cfu} / \mathrm{mL}$ after $3 \mathrm{~d}$ of incubation to $8.21 \pm 0.04 \log _{10} \mathrm{cfu} / \mathrm{mL}$ after $7 \mathrm{~d}$ of incubation.

For the Mycoplasma spp. isolates, the average enumerated isolate growth $( \pm$ SEM) was $4.62 \pm 0.07,4.55$ \pm 0.07 , and $4.51 \pm 0.07 \log _{10} \mathrm{cfu} / \mathrm{mL}$ when incubated for $7 \mathrm{~d}$ within a candle jar, $5 \% \mathrm{CO}_{2}$, or $10 \% \mathrm{CO}_{2}$, respectively, and differences were not significant $(P=$ 0.53 ; Figure 1). Enumerated growth was significantly greater with increasing incubation length $(P<0.0001$; Figure 2). Across all $\mathrm{CO}_{2}$ concentrations, enumerations $( \pm \mathrm{SEM})$ increased from $4.24 \pm 0.07 \log _{10} \mathrm{cfu} / \mathrm{mL}$ after $3 \mathrm{~d}$ of incubation to $4.89 \pm 0.07 \log _{10} \mathrm{cfu} / \mathrm{mL}$ after $7 \mathrm{~d}$ of incubation.

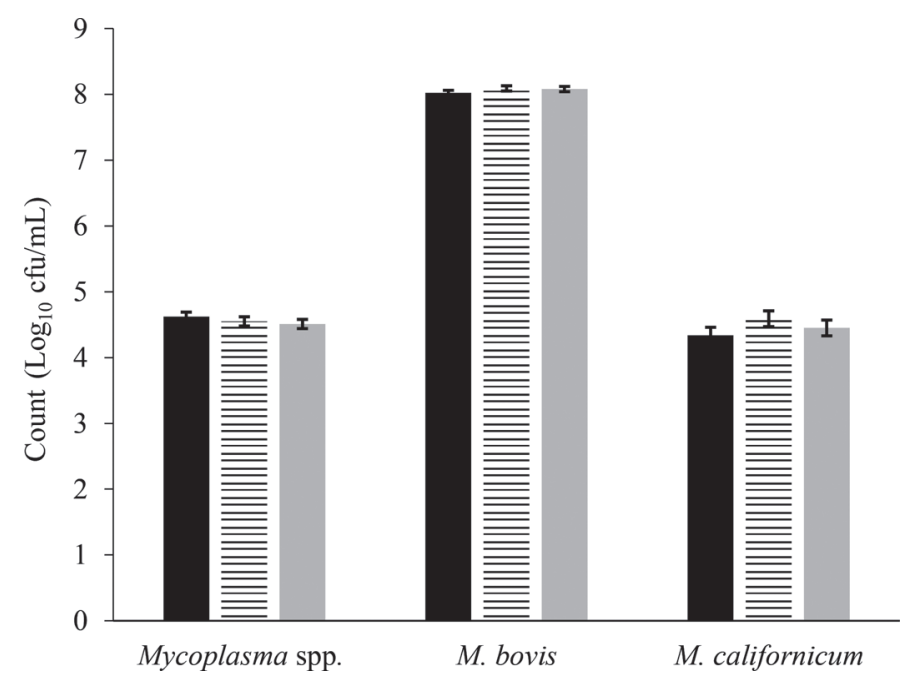

Figure 1. Growth $\left(\log _{10} \mathrm{cfu} / \mathrm{mL}\right) \pm$ SEM of each Mycoplasma species when laboratory isolates were incubated within a candle jar with $2.7 \pm 0.2 \% \mathrm{CO}_{2}$ (black bars) or in incubators of $5 \%$ (hatched bars) or $10 \%$ (gray bars) $\mathrm{CO}_{2}$ for $7 \mathrm{~d}$. 
Specifically, all M. bovigenitalium laboratory isolates were detected by $3 \mathrm{~d}$ of incubation regardless of $\mathrm{CO}_{2}$ concentration. All $M$. bovis laboratory isolates were detected by $3 \mathrm{~d}$ of incubation regardless of $\mathrm{CO}_{2}$ concentration. After $3 \mathrm{~d}$ of incubation, $90.9 \%$ of $M$. californicum laboratory isolates were detected when incubated within a candle jar or $5 \% \mathrm{CO}_{2}$ compared with $81.8 \%$ of isolates incubated in $10 \% \mathrm{CO}_{2}$. The percentage of isolates detected after $7 \mathrm{~d}$ of incubation increased to $100 \%$ regardless of $\mathrm{CO}_{2}$ concentration. The average enumeration of $M$. californicum isolates $( \pm \mathrm{SEM})$ was $4.34 \pm 0.12,4.59 \pm 0.12$, and $4.45 \pm 0.12 \log _{10} \mathrm{cfu} /$ $\mathrm{mL}$ when incubated for $7 \mathrm{~d}$ within a candle jar, $5 \%$ $\mathrm{CO}_{2}$, or $10 \% \mathrm{CO}_{2}$, respectively, and differences were not significant $(P=0.33$; Figure 1$)$. After $3 \mathrm{~d}$ of incubation, $90.9 \%$ of isolates were detected when incubated within a candle jar or $5 \% \mathrm{CO}_{2}$ compared with $81.8 \%$ of isolates incubated in $10 \% \mathrm{CO}_{2}$. The percentage of isolates detected after $7 \mathrm{~d}$ of incubation increased to $100 \%$ regardless of $\mathrm{CO}_{2}$ concentration, and the number of colonies counted was significantly greater after $7 \mathrm{~d}$ of incubation $\left(P<0.0001\right.$; Figure 2). Across all $\mathrm{CO}_{2}$ concentrations, enumerations $( \pm \mathrm{SEM})$ increased from $3.98 \pm 0.12 \log _{10} \mathrm{cfu} / \mathrm{mL}$ after $3 \mathrm{~d}$ of incubation to 4.74 $\pm 0.12 \log _{10} \mathrm{cfu} / \mathrm{mL}$ after $7 \mathrm{~d}$ of incubation.

\section{Field Isolates}

After freezer storage for 4 to 558 d, 98 of the 304 field samples $(32.24 \%)$ yielded growth for subsequent species identification (data not shown). Isolate species identi-

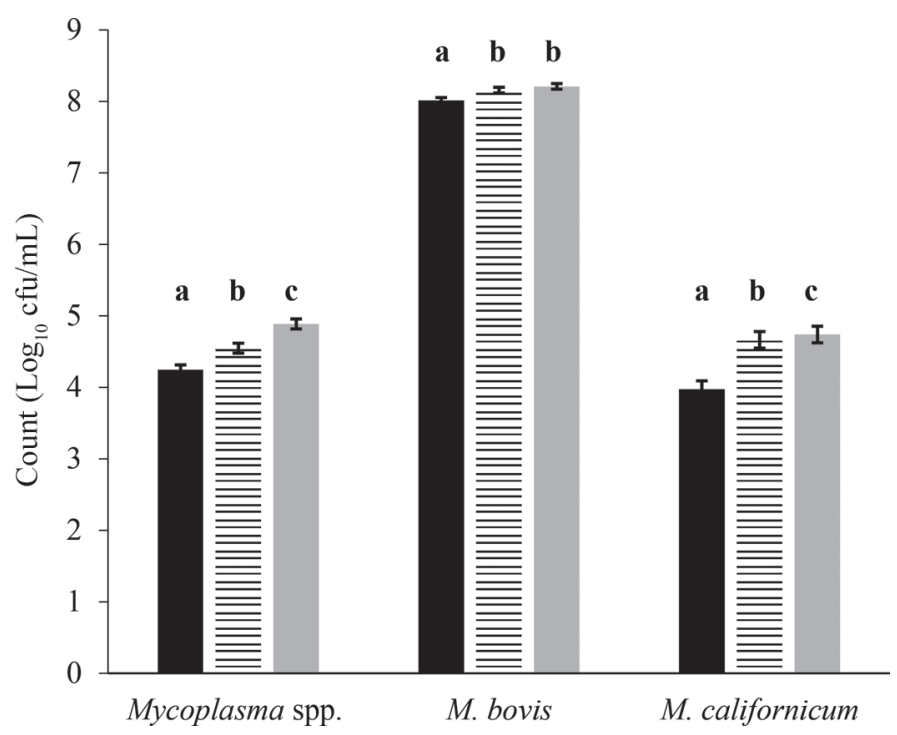

Figure 2. Growth $\left(\log _{10} \mathrm{cfu} / \mathrm{mL}\right) \pm$ SEM of each laboratory isolate Mycoplasma species after 3 (black bars), 5 (hatched bars), and 7 (gray bars) days of incubation. Bars with different letters (a-c) within species are significantly different $(P<0.05)$. fied by PCR-RFLP were as follows: A axanthum ( $\mathrm{n}=$ 4), M. bovis $(\mathrm{n}=64)$, M. californicum $(\mathrm{n}=26)$, and other Mycoplasma spp. $(\mathrm{n}=4)$. Isolates identified as other Mycoplasma spp. were presumptively M. arginini or M. canadense; however, due to similar amplicon sizes produced by chromosomal digests, a definitive species classification could not be made.

The proportion of isolates detected for each species was not significantly affected by the 3 tested atmospheric $\mathrm{CO}_{2}$ concentrations $(P=0.74)$. Overall, growth detection was significantly influenced by different species $(P<0.001)$. Not all isolates were detected on all days of incubation under all $\mathrm{CO}_{2}$ conditions: $85.26 \%$ of M. californicum, $82.61 \%$ of A axanthum, and $68.83 \%$ of $M$. bovis isolates could be enumerated on all days and under all $\mathrm{CO}_{2}$ conditions. Mycoplasma spp. isolates were detected on all days at all $\mathrm{CO}_{2}$ conditions.

The percentage of $A$. axanthum isolates ( \pm SEM) that could be detected on both $\mathrm{d} 3$ and 7 of incubation was $87 \pm 12.5,75 \pm 25$, and $87 \pm 12.5 \%$ within a candle jar and under 5 or $10 \% \mathrm{CO}_{2}$, respectively (Figure 3). Across all $\mathrm{CO}_{2}$ concentrations, the percentage of isolates identified increased $17 \%$ after d 7 of incubation (from $75 \pm 25 \%$ to $92 \pm 8.3 \%$; Figure 4 ). One A. axanthum isolate was not detected when incubated for $7 \mathrm{~d}$ under $5 \% \mathrm{CO}_{2}$.

For $M$. bovis, the percentage of isolates $( \pm$ SEM) that could be detected on both $\mathrm{d} 3$ and 7 was $68 \pm 5.2,71$ \pm 4.5 , and $67 \pm 4.7 \%$ within a candle jar and under 5 and $10 \% \mathrm{CO}_{2}$, respectively (Figure 3 ). Additionally, 48 $\pm 6.3 \%$ of $M$. bovis field isolates were detectable by 3 d of incubation, which increased to $92 \pm 3.4 \%$ after 7 $\mathrm{d}$ of incubation (Figure 4). Six M. bovis isolates were

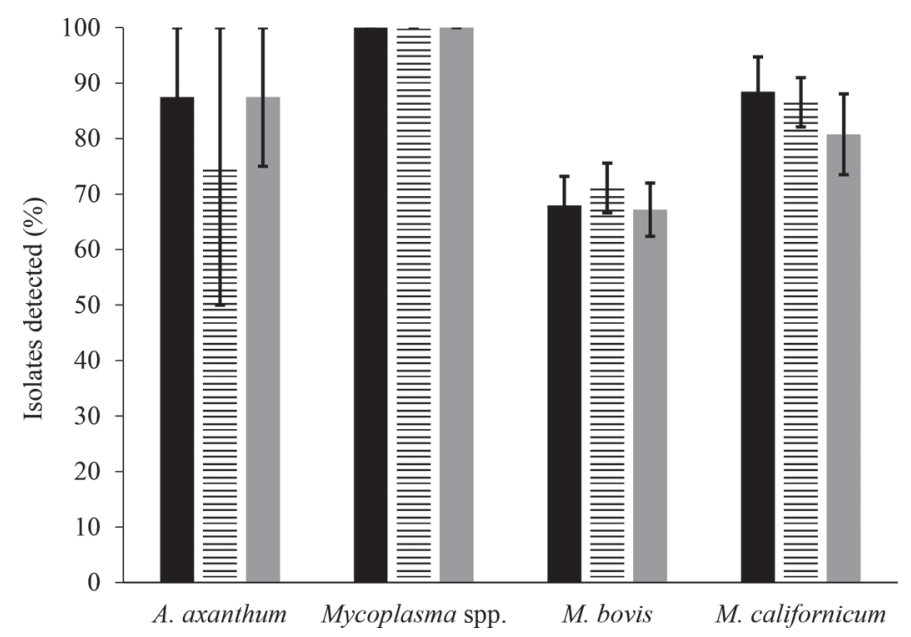

Figure 3. The percentage of isolates \pm SEM of each Acholeplasma or Mycoplasma species detected when field isolates were incubated within a candle jar with $2.7 \pm 0.2 \% \mathrm{CO}_{2}$ (black bars) or in incubators of $5 \%$ (hatched bars) or $10 \%$ (gray bars) $\mathrm{CO}_{2}$ for $7 \mathrm{~d}$. 
not detected when incubated for $7 \mathrm{~d}$ within a candle jar but were detected under the other $\mathrm{CO}_{2}$ concentrations; 2 isolates were not detected when incubated in $10 \%$ $\mathrm{CO}_{2}$ for $7 \mathrm{~d}$ but were detected under $5 \% \mathrm{CO}_{2}$ and when incubated within a candle jar. One isolate was detected only when incubated under $5 \% \mathrm{CO}_{2}$ for $7 \mathrm{~d}$, whereas another was detected only under $10 \% \mathrm{CO}_{2}$ and another only when incubated within a candle jar for $7 \mathrm{~d}$.

For M. californicum isolates, $88 \pm 6.3,87 \pm 4.4$, and $81 \pm 7.3 \%$ were detected on both d 3 and 7 of incubation within a candle jar and under 5 or $10 \% \mathrm{CO}_{2}$, respectively (Figure 3). After $3 \mathrm{~d}$ of incubation, $76 \pm$ $8.4 \%$ of $M$. californicum field isolates were detectable, which increased to $95 \pm 3.6 \%$ after $7 \mathrm{~d}$ of incubation (Figure 4). Two M. californicum isolates were never detected when incubated for $7 \mathrm{~d}$ within a candle jar, whereas another 2 isolates were never detected when incubated under $10 \% \mathrm{CO}_{2}$ for $7 \mathrm{~d}$.

\section{DISCUSSION}

\section{$\mathrm{CO}_{2}$ Concentrations}

Recommendations for atmospheric conditions when culturing mycoplasmas vary across disciplines, with conflicting reports of the efficacy of these concentrations (Edward, 1950; Fabricant et al., 1962; Polak-Vogelzang et al., 1983; Middleton et al., 2017). Perhaps most common is the use of a candle jar, $5 \% \mathrm{CO}_{2}$, and $10 \% \mathrm{CO}_{2}$. Work from Polak-Vogelzang et al. (1983) demonstrated that mycoplasma could be successfully cultured in a wide range of atmospheric conditions. They observed Mycoplasma hyorhinis subcultivation rates exceeding

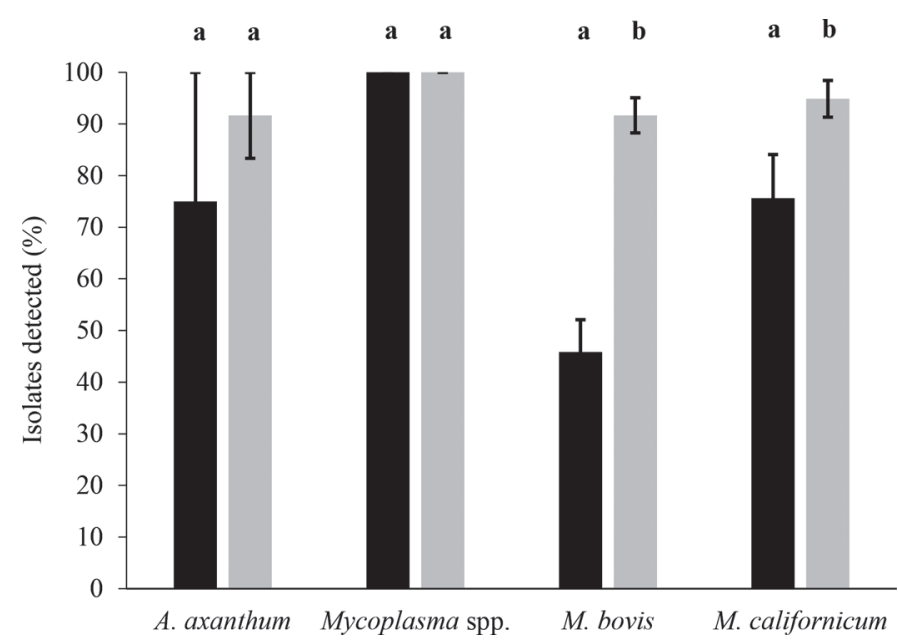

Figure 4. The percentage of isolates \pm SEM of each Acholeplasma or Mycoplasma species detected after 3 (black bars) and 7 (gray bars) days of incubation. Bars with different letters (a, b) within species are significantly different $(P<0.05)$.
$70 \%$ when isolates were incubated within a candle jar with $3 \%$ atmospheric $\mathrm{CO}_{2}$ or an incubator with a mixture of $6 \% \mathrm{CO}_{2}$ and hydrogen. Likewise, the American Type Culture Collection recommends cultivating Mycoplasma species within a candle jar or under $5 \%$ atmospheric $\mathrm{CO}_{2}$. Nicholas and Baker (1998) recommend a $5 \% \mathrm{CO}_{2}$ atmosphere when culturing Mycoplasma spp. from animal sources. On the other hand, Middleton et al. (2017) advocates culturing bovine mycoplasma isolates in a $10 \% \mathrm{CO}_{2}$ atmosphere for 7 to $10 \mathrm{~d}$, a recommendation derived from the first reported case of $M$. bovis mastitis by Hale et al. (1962). In their study, they did not detect growth when they used a conventional culture technique (blood agar, $37^{\circ} \mathrm{C}, 48 \mathrm{~h}$ ) but did when they used a $10 \% \mathrm{CO}_{2}$ environment for $5 \mathrm{~d}$. The utilization of a $10 \% \mathrm{CO}_{2}$ atmosphere was not empirically determined. Thus, the goal of the study was to determine whether growth of bovine Mycoplasma species differed under different $\mathrm{CO}_{2}$ concentrations so that veterinarians and diagnostic laboratories could select culture atmospheres that optimize mycoplasma isolation. Under the various $\mathrm{CO}_{2}$ concentrations (candle jar, $5 \% \mathrm{CO}_{2}$, or $10 \% \mathrm{CO}_{2}$ ), growth for both laboratory and field isolates was not significantly different for any species, suggesting that other factors may have a greater influence on growth of the mycoplasma isolates. It should be noted that growth of Mycoplasma species associated with mastitis was not tested under ambient atmospheric conditions. Such tests would have to be made in future studies to determine the extent of the advantage in detection of these pathogens under ambient as opposed to enriched $\mathrm{CO}_{2}$ conditions.

In this series of experiments, we inoculated pasteurized bulk tank milk with dilutions of isolates tested; milk was then incubated at $24 \mathrm{~h}$ before culture under test $\mathrm{CO}_{2}$ conditions. This preincubation step was done to acclimatize the various isolates to the milk medium and to partially emulate what might happen in vivo, where mycoplasma isolates are in the mammary gland milk at a similar temperature. This procedure appeared to result in increasing growth over time as the trend indicates that the longer the incubation time, the greater the enumeration (Figures 2 and 4). Parker et al. (2016) found that with a similar inoculation, the $M$. bovis recovery decreased in milk when held at $23^{\circ} \mathrm{C}$ and $37^{\circ} \mathrm{C}$.

\section{Factors Affecting Growth}

The isolates obtained from the field milk samples used in the study were first cultured by the veterinary diagnostic laboratory and frozen for up to 19 mo before they were donated to the Washington State University Field Disease Investigative Unit laboratory. Only $32 \%$ 
of all field isolates yielded growth by $7 \mathrm{~d}$ of incubation. A low concentration of cells coupled with freezer morbidity may have increased the likelihood of no growth. Biddle et al. (2004) observed that freezing mycoplasma samples at $-20^{\circ} \mathrm{C}$ for $4 \mathrm{wk}$ resulted in a 3 to $4 \log _{10} \mathrm{cfu} /$ $\mathrm{mL}$ reduction in viable cells, and recovery decreased with increasing episodes of freezing and thawing. The effects of repeated freeze-thawing and prolonged storage times may have reduced the number of viable cells within the original sample that were in some cases stored for more than 1 yr. Cai et al. (2005) suggested that a minimum of $100 \mathrm{cfu} / \mathrm{mL}$ of milk can be reliably detected using bacterial culture. The limit of detection in this study was $100 \mathrm{cfu} / \mathrm{mL}$, and thus any samples containing organisms below this threshold would not have yielded observable growth. Although Sachse et al. (2010) noted that in practice a positive culture below $1,000 \mathrm{cfu} / \mathrm{mL}$ of milk was rarely found, a 4 -log reduction due to storage would make detecting that level unlikely.

Beyond sample handling, the concentration of viable cells, and storage time, the growth of Mycoplasma spp. is dependent on culture conditions. Mycoplasmas have special growth requirements that are distinct from most mastitis pathogens, requiring specialized media, nonatmospheric $\mathrm{CO}_{2}$ concentrations, and prolonged incubation periods of up to $10 \mathrm{~d}$ (Bushnell, 1984). For all isolates observed in this study, growth was significantly greater after $7 \mathrm{~d}$ of incubation compared with 3 $\mathrm{d}$ of incubation $(P<0.05)$. Mycoplasma spp., M. bovis, and $M$. californicum isolates increased by $0.65,0.17$, and $0.76 \log _{10} \mathrm{cfu} / \mathrm{mL}$, respectively, when incubated for $7 \mathrm{~d}$. Perhaps more important, all $M$. bovis and $M$. bovigenitalium isolates were detected by $3 \mathrm{~d}$ of incubation and all $M$. californicum isolates were detected by $5 \mathrm{~d}$ of incubation regardless of $\mathrm{CO}_{2}$ concentration. It is possible that the subculturing protocol applied to the banked isolates selected for faster growing isolates when the 3 -d culture was spread onto the surface of a modified Hayflick's agar plate. To determine whether this selection effect had occurred, the effect of incubation length was evaluated in the field isolates as well.

Middleton et al. (2017) and Maunsell et al. (2011) recommend incubation periods of 7 to $10 \mathrm{~d}$ before samples are considered negative. Our results support this recommendation, as the likelihood of detecting field isolates from d 3 to 7 increased $17 \%$ for $A$. axanthum, $46 \%$ for M. bovis, and $19 \%$ for M. californicum field isolates. Strain differences within species were present, which would explain why $100 \%$ detection was not achieved. Overall, after $7 \mathrm{~d}$ of incubation, 4\% (4/98) of field isolates were not detected when incubated under $5 \% \mathrm{CO}_{2}$, $7 \%(7 / 98)$ were not detected when incubated under
$10 \% \mathrm{CO}_{2}$, and $10 \%(10 / 98)$ were not detected when incubated within a candle jar. This suggests that no single $\mathrm{CO}_{2}$ concentration yields $100 \%$ detection of field isolates. Significant differences in growth and growth detection for bovine mycoplasma isolates under the $\mathrm{CO}_{2}$ concentrations were not found; however, the use of candle jars slightly increases the risk of false negatives as $10 \%$ of field isolates were not detected after $7 \mathrm{~d}$ of incubation. For the producer and the diagnostic laboratories, allowing $7 \mathrm{~d}$ of incubation increases the test sensitivity, resulting in fewer false negatives and, subsequently, missing fewer cows infected with mycoplasma. The fact that many isolates could be detected in as few as $3 \mathrm{~d}$ is important. For such isolates, the reduced incubation time leads to more timely reporting of results to the producer, who can then make more timely management decisions with respect to the infected animals. On the other hand, approximately twice as many $M$. bovis isolates were detected after $7 \mathrm{~d}$ than after $3 \mathrm{~d}$. Anecdotal comments from local diagnostic laboratories indicate that there is a preference for examining growth of suspected Mycoplasma spp.-positive cultures at 3 and $7 \mathrm{~d}$. In addition, in our study of laboratory isolates it was observed that there was no difference in growth between $\mathrm{d} 3$ and 5 and no difference in growth between d 5 and 7 , but there was a significant difference in growth of Mycoplasma spp. in general when growth at d 3 was compared with growth at d 7 . For these reasons, we chose to compare growth at d 3 and 7 in our study of field isolates. Therefore, mollicute cultures might be best incubated for at least $7 \mathrm{~d}$ in the absence of growth and this absence reported as indeterminate rather than negative until after $7 \mathrm{~d}$ have passed.

\section{CONCLUSIONS}

Mycoplasma infections in dairy cattle are often persistent, difficult to cure, and challenging to diagnose. Due to the contagious nature, identification of infected cows is important in the control of the disease. These results suggest that no significant growth difference occurs between candle jar, $5 \% \mathrm{CO}_{2}$, or $10 \% \mathrm{CO}_{2}$ atmospheres. Laboratories using candle jars may not be at a significant disadvantage for detecting mycoplasma mastitis pathogens compared with laboratories using $\mathrm{CO}_{2}$ incubators. Consistent with the literature, we found that colonies may be detected by $3 \mathrm{~d}$ of incubation but that $7 \mathrm{~d}$ of incubation resulted in a greater proportion of positive plates. In summary, the range of $\mathrm{CO}_{2}$ concentrations and incubation times suitable for cultivating and identifying bovine mycoplasma mastitis pathogens may be broader than those recommended by the National Mastitis Council. 


\section{REFERENCES}

Amin, M. M., and F. T. W. Jordan. 1978. A comparative study of some cultural methods in the isolation of avian mycoplasma from field material. Avian Pathol. 7:455-470.

Biddle, M. K., L. K. Fox, D. D. Hancock, C. T. Gaskins, and M. A. Evans. 2004. Effects of storage time and thawing methods on the recovery of Mycoplasma species in milk samples from cows with intramammary infections. J. Dairy Sci. 87:933-936.

Boonyayatra, S., L. K. Fox, T. E. Besser, A. Sawant, J. M. Gay, and Z. Raviv. 2012. A PCR assay and PCR-restriction fragment length polymorphism combination identifying the 3 primary Mycoplasma species causing mastitis. J. Dairy Sci. 95:196-205.

Bushnell, R. B. 1984. Mycoplasma mastitis. Vet. Clin. North Am. Large Anim. Pract. 6:301-312.

Cai, H. Y., P. Bell-Rogers, L. Parker, and J. F. Prescott. 2005. Development of a real-time PCR for detection of Mycoplasma bovis in bovine milk and lung samples. J. Vet. Diagn. Invest. 17:537-545.

Edward, D. G. 1950. An investigation of the biological properties of organisms of the pleuropneumonia group, with suggestions regarding the identification of strains. J. Gen. Microbiol. 4:311-329.

Fabricant, C. G., P. T. Van Denmark, and J. Fabricant. 1962. The effect of atmospheric environment upon the growth of Mycoplasma gallisepticum. Avian Dis. 6:328-332.

Fox, L. K. 2012. Mycoplasma mastitis: Causes, transmission and control. Vet. Clin. North Am. Food Anim. Pract. 28:225-237.

Fox, L. K., J. H. Kirk, and A. Britten. 2005. Mycoplasma mastitis: A review of transmission and control. J. Vet. Med. B Infect. Dis. Vet. Public Health 52:153-160.

González, R. N., and D. J. Wilson. 2003. Mycoplasma mastitis in dairy herds. Vet. Clin. North Am. Food Anim. Pract. 19:199-221.

Hale, H. H., C. F. Helmboldt, W. N. Plastridge, and E. F. Stula. 1962. Bovine mastitis caused by a Mycoplasma species. Cornell Vet. 52:582-591.

Jasper, D. E. 1982. The role of mycoplasma in bovine mastitis. J. Am. Vet. Med. Assoc. 181:158-162.

Kotani, H., G. Butler, and D. Tallarida. 1990. Microbiological cultivation of Mycoplasma hyorhinis from cell cultures. In Vitro Cell. Dev. Biol. 26:91-96.
Maunsell, F. P., A. R. Woolums, D. Francoz, R. F. Rosenbusch, D L. Step, D. J. Wilson, and E. D. Janzen. 2011. Mycoplasma bovis infections in cattle. J. Vet. Intern. Med. 25:772-783.

Middleton, J. R., L. K. Fox, and G. Pighetti. 2017. Laboratory Handbook of Bovine Mastitis. 3rd ed. National Mastitis Council, New Prague, MN.

Nicholas, R., and S. Baker. 1998. Recovery of mycoplasmas from animals. Methods Mol. Biol. 104:37-43.

Parker, A. M., J. K. House, M. S. Hazelton, K. L. Bosward, V. L. Mohler, F. P. Maunsell, and P. A. Sheehy. 2016. Milk acidification to control the growth of Mycoplasma bovis and Salmonella Dublin in contaminated milk. J. Dairy Sci. 99:9875-9884.

Parker, A. M., J. K. House, M. S. Hazelton, K. L. Bosward, and P. A. Sheehy. 2017. Comparison of culture and a multiplex probe PCR for identifying Mycoplasma species in bovine milk, semen, and swab samples. PLoS One 12:e173422.

Polak-Vogelzang, A. A., H. H. De Haan, and J. Borst. 1983. Comparison of various atmospheric conditions for isolation and subcultivation of Mycoplasma hyorhinis from cell cultures. Antonie van Leeuwenhoek 49:31-40.

Punyapornwithaya, V., L. K. Fox, D. D. Hancock, J. M. Gay, and R. Alldredge. 2010. Association between an outbreak strain causing Mycoplasma bovis mastitis and its asymptomatic carriage in the herd: A case study from Idaho, USA. Prev. Vet. Med. 93:66-70.

Rosengarten, R., and C. Citti. 1999. The role of ruminant mycoplasmas in systemic infection. Pages 14-17 in Mycoplasmas of Ruminants: Pathogenicity, Diagnostics, Epidemiology and Molecular Genetics. L. Stipkovits, R. Rosengarten, and J. Frey, ed. European Commission, Brussels, Belgium.

Sachse, K., H. S. H. Salam, R. Diller, E. Schubert, B. Hoffmann, and H. Hotzel. 2010. Use of a novel real-time PCR technique to monitor and quantitate Mycoplasma bovis infection in cattle herds with mastitis and respiratory disease. Vet. J. 186:299-303.

Stipkovits, L., A. A. El-Ebeedy, J. Kisary, and L. Varga. 1975. Mycoplasma infection of geese I. Incidence of Mycoplasmas and Acholeplasmas in geese. Avian Pathol. 4:35-43.

Tang, J., M. Hu, S. Lee, and R. Roblin. 2000. A polymerase chain reaction based method for detecting Mycoplasma/Acholeplasma contaminants in cell culture. J. Microbiol. Methods 39:121-126. 